\section{'Nocturne' Hybrid Blueberry: A Winter-hardy, Mixed-species Hexaploid with Ornamental Landscape Interest and Novel Fruit Quality}

\author{
Mark K. Ehlenfeldt ${ }^{1}$ and Robert B. Martin \\ Marucci Center for Blueberry and Cranberry Research and Extension, \\ Agricultural Research Service, United States Department of Agriculture, \\ Chatsworth, NJ 08019; and Genetic Improvement of Fruits and Vegetables \\ Laboratory, Agricultural Research Service, United States Department of \\ Agriculture, Beltsville, MD 20705
}

\section{Lisa J. Rowland \\ Genetic Improvement of Fruits and Vegetables Laboratory, Agricultural Research Service, United States Department of Agriculture, Agricultural Research Service, Beltsville, MD 20705}

Additional index words. cold hardiness, rabbiteye, Vaccinium ashei, Vaccinium constablaei, Vaccinium virgatum

\begin{abstract}
'Nocturne' is a dark-fruited, hexaploid blueberry selection with significant $(50 \%)$ rabbiteye (Vaccinium ashei Reade, syn. Vaccinium virgatum Aiton) ancestry for use as a specialty market plant for homeowner, landscape, and ornamental use. 'Nocturne' is notable for its ornamental qualities and unique flavor. 'Nocturne's unripe fruit is vivid, red-orange and is set against glossy green foliage on a vigorous, upright, and slightly spreading plant. 'Nocturne's ripe fruit is sweet, medium-sized, and dusky gunmetal black, ripening in late midseason to late season. 'Nocturne' is unique among rabbiteye-type germplasm in having outstanding winterhardiness, and an extended dormancy period similar to northern highbush (Vaccinium corymbosum L.). Both of these characters derive from its Vaccinium constablaei Gray ancestry.
\end{abstract}

\section{Origin}

'Nocturne' (Vaccinium $\times$ 'Nocturne'), tested as US 1056, is a cross of US $874[\mathrm{~V}$. constablaei $\times$ NJ 89-158-8 (a hexaploid mixed-species hybrid)] $\times$ 'Premier' ( $V$. ashei, syn. V. virgatum) (Fig. 1). The cross that produced 'Nocturne' was made by M.K. Ehlenfeldt (USDA-ARS) at the Marucci Center for Blueberry and Cranberry Research and Extension, Chatsworth, NJ, in 1993. 'Nocturne' is an offspring from a program designed to produce northern-adapted rabbiteye cultivars (Ehlenfeldt and Rowland, 2015; Ehlenfeldt et al., 2007). Critical in the

Received for publication 29 Sept. 2015. Accepted for publication 8 Oct. 2015. ars.usda.gov.
${ }^{1}$ Corresponding author. E-mail: mark.ehlenfeldt@ development of such material is the use of $V$. constablaei, a cold-hardy, a high-altitude species found in the southeastern United States.

'Nocturne' was selected in 1996, and was evaluated in a single-plant plot in Chatsworth by M.K. Ehlenfeldt and R.B. Martin from 1996 to 2011. 'Nocturne' was subsequently evaluated by these researchers in a replicated plot at Variety Farms, a commercial farm in Hammonton, NJ, in 2013 and 2014. This plot consisted of four reps of two plants each in a replicated design. The trials were located in U.S. Department of Agriculture (USDA) Plant Hardiness Zone 6 , on soils that are mostly Atsion-Berryland sand containing $3 \%$ to $15 \%$ organic matter. Cultural practices included the use of drip irrigation.

\section{Description}

'Nocturne' is most immediately notable for, and has been released for, its ornamental qualities. 'Nocturne's unripe fruit is vivid, red-orange and is set against glossy green foliage on a vigorous, upright, slightly spreading plant (Fig. 2A). This combination of characteristics produces a plant with unique landscape interest across a period of several weeks in midsummer when the fruit is immature (Fig. 2B). As fruit ripens, it darkens to dusky gunmetal black (Fig. 2B). During the ripening period, plants will have both ripe and unripe fruit for several weeks.

'Nocturne' is also notable for having winterhardiness comparable to northern highbush blueberry cultivars. Evaluations have shown that 'Nocturne' reaches a maximal $\mathrm{LT}_{50}$ (temperature causing 50\% flower bud lethality) of $\approx-25{ }^{\circ} \mathrm{C}$ by late December (Ehlenfeldt et al., 2012). Like northern highbush cultivars (such as Bluecrop), it maintains these levels for $\approx 7$ weeks (until early February), before beginning to deacclimate (Fig. 3). Other cultivars and selections derived from southern germplasm such as 'Tifblue' (rabbiteye) or 'Legacy' (southern highbush) reach maximum cold hardiness in late December, but thereafter begin to deacclimate at relatively linear rates even though mean environmental temperatures may continue to decline. This extended period of dormancy in 'Nocturne' is unique among rabbiteye-type germplasm. The $V$. constablaei ancestry also contributes a late-flowering characteristic to 'Nocturne'. 'Nocturne' typically flowers as late as, or later than, late-flowering highbush (Fig. 4). We believe this character contributes to Nocturne's reliable cropping under mid-Atlantic temperate conditions. Late flowering, in this and other selections, promises to be a strategically useful trait as climate change induces more erratic temperature conditions.

'Nocturne' flowers have a bright white albedo. Its flowers are broadly urceolate, about equal in length and width, with a broad aperture in well-developed flowers; however, they often display split, distorted and/or reduced corollas much like those of its rabbiteye parent, 'Premier' (Sampson et al., 2013) (Fig. 2C). Like 'Premier', 'Nocturne' has styles that are exerted before pollen shed

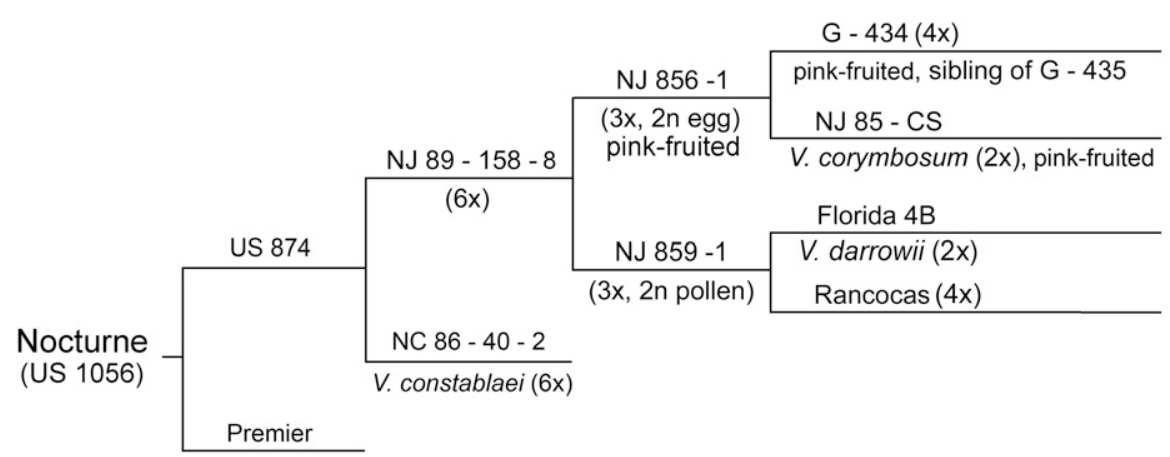

Fig. 1. Pedigree of 'Nocturne', a mixed-species hexaploid blueberry. The G-434 ancestor is a full-sib of a selection described by Ehlenfeldt and Finn (2007), and composed primarily of Vaccinium corymbosum L. with small contributions from Vaccinium darrowii Camp, Vaccinium tenellum Aiton and Vaccinium ashei Reade (syn. Vaccinium virgatum Aiton). 


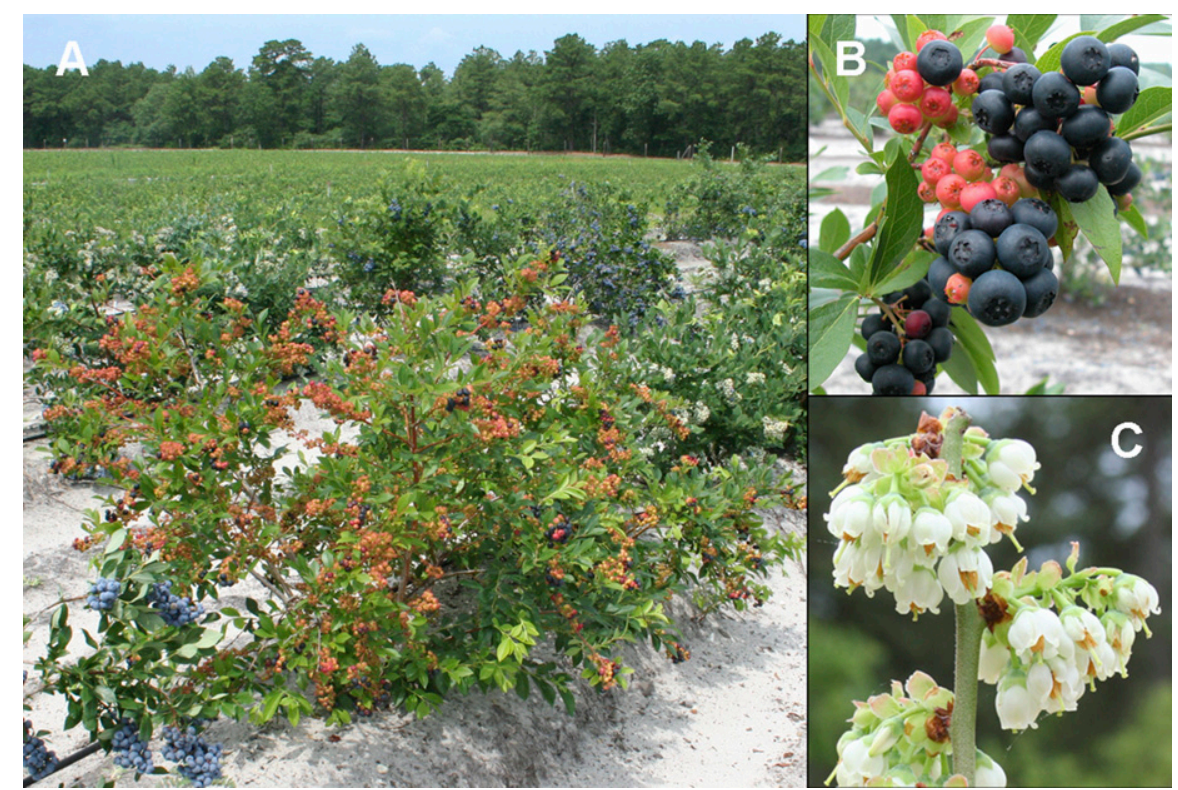

Fig. 2. 'Nocturne' cold-hardy rabbiteye hybrid: (A) plant habit (four-year-old plants), (B) ripe and unripe fruit, (C) flowers.

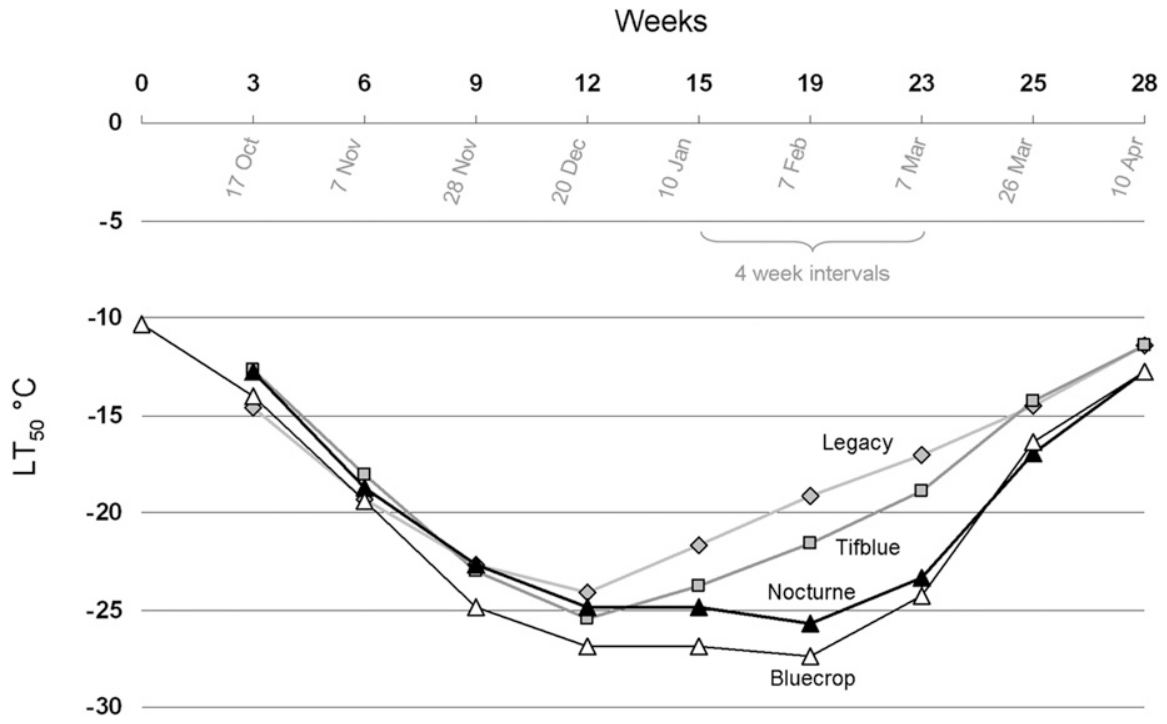

Fig. 3. Acclimation and deacclimation of 'Bluecrop' (northern highbush), 'Nocturne' (northern-adapted rabbiteye), 'Tifblue' (rabbiteye), and 'Legacy' (southern highbush) over a 2-year period (modified from Ehlenfeldt et al., 2012). $\mathrm{LT}_{50}$ is the temperature causing $50 \%$ flower bud lethality.
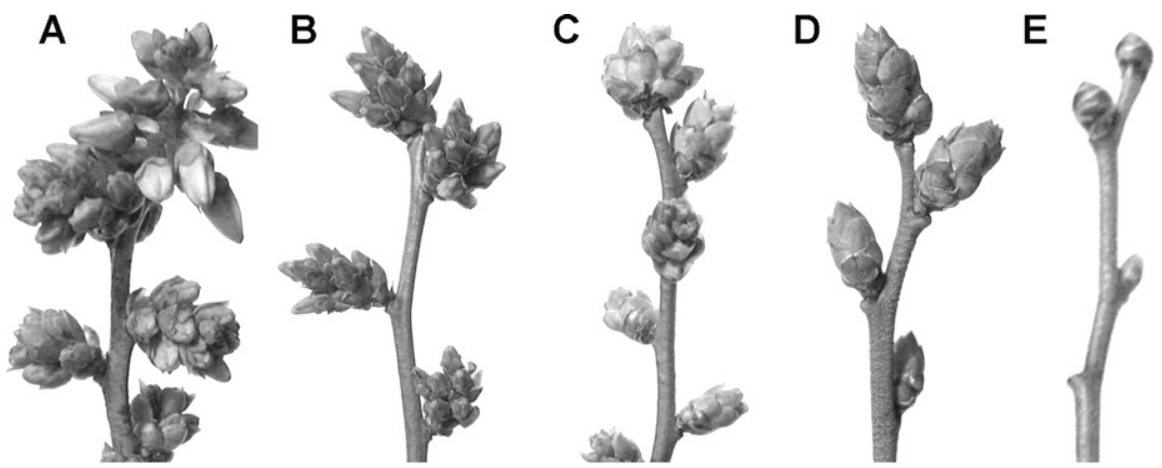

Fig. 4. Relative flower bud development of (A) 'Bluecrop', (B) 'Tifblue', $(\mathbf{C})$ 'Nocturne', and (D and $\mathbf{E})$ two Vaccinium constablaei clones on 22 Apr. 2004.
(Ehlenfeldt, personal observation). Pollen is shed freely from 'Nocture' flowers and is released when flowers are even lightly disturbed. 'Nocturne' has been shown to be highly self-fertile. 'Nocturne' fruit-set when self-pollinated was comparable to highbush cultivars, unlike the hexaploid rabbiteye cultivars we tested (Ehlenfeldt and Kramer, 2012).

For initial evaluations of the mother plant from 1996 to 2012, 'Nocturne' was compared with the standard cultivar Duke, which is productive, firm, and considered to be generally late flowering (Draper et al., 1987). In these evaluations, 'Nocturne' was seen to have a $50 \%$ flowering date that was $10 \mathrm{~d}$ later than 'Duke' (15 May vs. 5 May), making 'Nocturne' among the latest flowering selections or cultivars we observed. 'Nocturne' ripened in mid-July ( $50 \%$ ripe on 11 July) in the period between 'Bluecrop' and 'Elliott' in New Jersey. 'Nocturne' fruit is sweet, delicious, and juicy, with appealing volatiles, and a unique flavor atypical of either highbush or rabbiteye. 'Nocturne' was observed to have high soluble solids $(13.6 \%)$, good flavor ( 7.8 on a 1-9 scale), and moderate size (7.5 rating). 'Nocturne's scar was rated as fair (6.8 rating), and firmness moderate (156 g. $\mathrm{mm}^{-1}$ deflection, similar to 'Bluecrop') (Table 1). Fruit storage and shipping capacity of 'Nocturne' is limited. The fair scar, moderate firmness, and low wax content indicate that 'Nocturne' would not be suitable for commercial harvest or shipping without extraordinary effort. 'Nocturne' is recommended primarily as a landscape ornamental/culinary, a specialty, or a pick-yourown variety.

Replicated tests in the grower plot in 2013 and 2014, confirmed these results. In these tests, 'Nocturne' ripened somewhat later (19 July), but still fell between 'Bluecrop' and 'Elliott' (Table 2). This difference in date is likely due to differences in local climatic conditions, and a slightly less mature bush size. Fruit size was comparable to 'Elliott' at $1.6 \mathrm{~g}$. The yields in these plots were also comparable to 'Elliott' under New Jersey conditions at $>4 \mathrm{~kg} /$ plant.

'Nocturne' is an upright plant with a moderate suckering tendency, and a somewhat sprawling habit. It grows vigorously, and mature plants of 'Nocturne' may reach dimensions of $1.5 \mathrm{~m}$ (height) $\times 1.7 \mathrm{~m}$ (width). Studies in New Jersey have shown that 'Nocturne' is relatively susceptible to mummy berry blight caused by the fungus Monilinia vaccinii-corymbosi Reade (Honey), and has average resistance to the secondary, fruit-infection stage (unpublished data). 'Nocturne' also has probable Blueberry red ringspot virus resistance, based on field observations.

'Nocturne' is the parent of the ornamental cultivar Summer Sunset ${ }^{\mathrm{TM}}$ patented by the University of Georgia (NeSmith and Ehlenfeldt, 2011). These two cultivars have morphological and coloration similarities; however, whereas 'Nocturne' has demonstrated cold hardiness, 
Table 1. Character value means for 'Duke' northern highbush and 'Nocturne' mixed-species hexaploid blueberry in a single-plant test plot in Chatsworth, NJ, 1996-2011.

\begin{tabular}{|c|c|c|c|c|c|c|c|c|c|}
\hline & $\begin{array}{l}\text { Date } 50 \% \\
\text { flowering }\end{array}$ & $\begin{array}{l}\text { Date } 50 \% \\
\text { ripe }\end{array}$ & $\operatorname{Size}^{z}$ & Scar $^{2}$ & Color $^{z}$ & $\begin{array}{c}\text { Firmness } \\
\left(\mathrm{g} \cdot \mathrm{mm}^{-1} \mathrm{dfl}\right)^{\mathrm{y}}\end{array}$ & Flavor $^{z}$ & $\begin{array}{l}\text { Soluble solids } \\
(\%)\end{array}$ & $\begin{array}{l}\text { Titratable acidity } \\
\text { (\% citric acid) }\end{array}$ \\
\hline 'Duke' & 5 May & 26 June & 8 & 8 & 8.3 & 187 & 7 & 10.2 & 0.44 \\
\hline 'Nocturne' & 15 May & 11 July & 7.5 & 6.8 & 4.5 & 156 & 7.8 & 13.6 & 0.56 \\
\hline
\end{tabular}

${ }^{\mathrm{z} R a t i n g s}$ on a $1-9$ scale; 9 = superior.

${ }^{y}$ Grams of force needed to produce $1 \mathrm{~mm}$ of deflection, averaged across 30 intact fruit.

Table 2. Fruit weight, color, firmness, soluble solids, titratable acidity, estimated 50\% ripening dates, and representative yields for 'Nocturne' and 'Elliott' summarized across harvests at Chatsworth, NJ (2010, 2012) and across harvests and replicates at Variety Farms, Hammonton, NJ (2013, 2014).

\begin{tabular}{|c|c|c|c|c|c|c|c|c|}
\hline Cultivar & $\begin{array}{l}\text { Berry wt } \\
(\mathrm{g})\end{array}$ & $\begin{array}{l}\text { Color } \\
(\mathrm{L})^{\mathrm{z}}\end{array}$ & $\begin{array}{l}\text { Firmness } \\
\left(\mathrm{g} \cdot \mathrm{mm}^{-1}\right)^{\mathrm{y}}\end{array}$ & Soluble solids ${ }^{\mathrm{x}}$ & $\begin{array}{l}\text { Titratable acidity } \\
(\% \text { citric acid })^{x}\end{array}$ & Date $50 \%$ ripe & Harvest interval & $\begin{array}{c}\text { Yield per plant } \\
(\mathrm{kg})\end{array}$ \\
\hline \multicolumn{9}{|l|}{ Nocturne } \\
\hline 2010 & $2.0 \pm 0.4$ & 32.0 & $156 \pm 56$ & 14.8 & 0.62 & $60 \%$ on 6 July & $<6$ July-20 July & 5.3 \\
\hline 2012 & $1.8 \pm 0.3$ & - & $159 \pm 35$ & - & - & - & - & - \\
\hline 2013 & $1.1 \pm 0.4$ & 30.2 & $162 \pm 47$ & 12.6 & 0.58 & 23 July & 15 July-12 Aug & $4.6 \pm 0.6$ \\
\hline 2014 & $1.5 \pm 0.02$ & 24.4 & $149 \pm 41$ & 13.6 & 0.63 & 14 July & 10 July-31 July & $4.1 \pm 1.0$ \\
\hline \multicolumn{9}{|l|}{ Elliott } \\
\hline 2010 & $1.5 \pm 0.3$ & 66.2 & - & 10.8 & 0.97 & $52 \%$ on 20 July & 20 July-3 Aug. & 4.0 \\
\hline 2012 & $1.8 \pm 0.5$ & - & $135 \pm 37$ & - & - & - & - & - \\
\hline 2013 & $1.8 \pm 0.4$ & 65.4 & $165 \pm 33$ & 11.6 & 1.25 & 29 July & 22 July-12 Aug & $3.9 \pm 1.0$ \\
\hline 2014 & $1.3 \pm 0.1$ & 54.4 & $115 \pm 22$ & 11.0 & 1.41 & 11 Aug. & 23 July-19 Aug. & $4.4 \pm 0.9$ \\
\hline \multicolumn{9}{|l|}{ Averages } \\
\hline Nocturne & $1.6 \pm 0.3$ & 28.8 & $157 \pm 41$ & $13.7 \pm 1.1$ & $0.61 \pm 0.03$ & 19 Julyw & 10 July-31 Julyw & $4.6 \pm 0.8^{w}$ \\
\hline Elliott & $1.6 \pm 0.3$ & 62.0 & $139 \pm 25$ & $11.1 \pm 0.4$ & $1.21 \pm 0.22$ & 5 Aug. & 22 July-11 July & $4.1 \pm 1.0$ \\
\hline
\end{tabular}

${ }^{\mathrm{z}}$ Color in the L*a*b* color coordinate system as defined by the Commission Internationale 1'Eclairage (CIE). L coordinate indicates lightness; higher numbers indicate lighter color. Color meter aperture, $50 \mathrm{~mm}$.

${ }^{y}$ Grams of force needed to produce $1 \mathrm{~mm}$ of deflection, averaged across 30 intact fruit.

${ }^{\mathrm{x}}$ Soluble solids and titratable acidity were determined on a blended one cup sample of fruit.

${ }^{\mathrm{w}}$ Averages for date of 50\% ripe, harvest interval, and yield per plant represent values across 2013-14, at Hammonton, NJ.

'Summer Sunset ${ }^{\mathrm{TM}}$ ' being $>75 \%$ rabbiteye is expected to be primarily southern adapted.

\section{Availability}

'Nocturne' is released unconditionally with no warranty given regarding its performance or adaptation under specific environmental or cultural conditions. The USDA-ARS has patented this cultivar (Ehlenfeldt, 2014) and it is available for licensing on a nonexclusive basis. Nurseries interested in this cultivar may request information on licensing by contacting M.K. Ehlenfeldt, USDA-ARS, Marucci Center for Blueberry and Cranberry Research and Extension, 125A Lake Oswego Road, Chatsworth, NJ 08019. Researchers interested in evaluating 'Nocturne' may request informa- tion regarding testing under a Material Transfer Agreement.

\section{Literature Cited}

Draper, A., G. Galletta, G. Jelenkovic, and N. Vorsa 1987. 'Duke' highbush blueberry. HortScience 28:320.

Ehlenfeldt, M.K. 2014. Blueberry Plant Named Nocturne. U.S. Plant Patent 24,832 P2, filed 28 Sept. 2012 and issued 22 Sept. 2014.

Ehlenfeldt, M.K. and C.E. Finn. 2007. G-435 and ARS 96-138, pink-fruited blueberry selections. HortScience 42:172-173.

Ehlenfeldt, M.K. and M. Kramer. 2012. Selffertility evaluations of northern-adapted rabbiteye blueberry hybrids. HortScience 47:18371842.

Ehlenfeldt, M.K., L.J. Rowland, E.L. Ogden, and B.T. Vinyard. 2007. Floral bud cold hardiness of Vaccinium ashei, V. constablaei, and hybrid derivatives and their potential for producing northern-adapted rabbiteye cultivars. HortScience 42:1131-1134.

Ehlenfeldt, M.K., L.J. Rowland, E.L. Ogden, and B. Vinyard. 2012. Cold-hardiness, acclimation, and deacclimation among diverse blueberry genotypes. J. Amer. Soc. Hort. Sci. 137:31-37.

Ehlenfeldt, M.K. and L.J. Rowland. 2015. Utilizing $V$. constablaei and $V$. ashei in germplasm and cultivar development. Proc. 12th North Amer. Blueberry Res. Ext. Workers Conf. doi: 10.7282/T35140W5.

NeSmith, D.S. and M.K. Ehlenfeldt. 2011. 'Summer Sunset ${ }^{\mathrm{TM}}$ ': A new ornamental blueberry. HortScience 46:1560-1561.

Sampson, B.J., S.J. Stringer, and D.A. Marshall. 2013. Blueberry floral attributes and their effect on the pollination efficiency of an oligolectic bee, Osmia ribifloris Cockerell (Megachilidae: Apoidea). HortScience 48:136-142. 